\title{
AL-IQTISHADIYAH
}

Jurnal Ekonomi Syariah dan Hukum Ekonomi Syariah

E-ISSN: 2621-0274; P-ISSN: 2442-2282

Volume 7, Nomor 1, Juni 2021

\section{Pengaruh Brand Image dan Labelitas Halal Terhadap Keputusan Pembelian Kosmetik pada IPPNU Kabupaten Mojokerto}

\author{
Putri Rizki Amalia', Nur Dinah Fauziah'², Diah Syifaul A'yuni ${ }^{3}$ \\ 1 Institut Pesantren KH. Abdul Chalim, Indonesia. E-mail: Putririzkiamalia160997@gmail.com \\ 2 Institut Pesantren KH. Abdul Chalim, Indonesia. E-mail: Dina.fau@gmail.com \\ 3 Institut Pesantren KH. Abdul Chalim, Indonesia. E-mail: Diah.ayun87@gmail.com
}

\section{ARTICLE INFO}

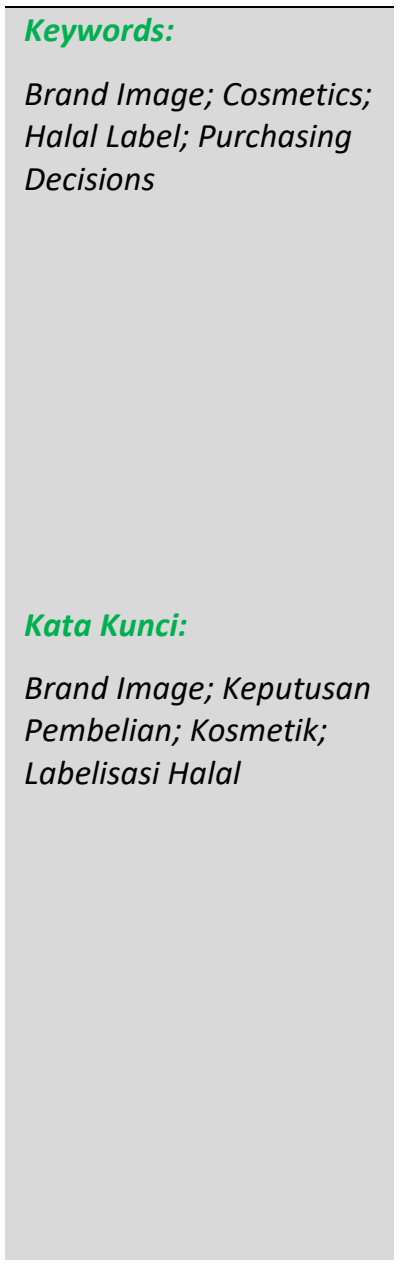

\section{ABSTRACT}

This thesis aims to determine the effect of brand image and halal labelity on cosmetics purchasing decisions in IPPNU Mojokerto districts. This study uses quantitative research using primary data obtained from filling out questionnaires regarding brand image and halal labeling on purchasing decisions for cosmetic products, which then analyzed using multiple regression method. The results of the study shows that brand image and halal labelity simultaneously affect the purchasing decisions cosmetics of IPPNU Mojokerto Districts. Brand image has positive and significant effect on the decision to purchase cosmetics in IPPNU Mojokerto Districts. Halal labeling also has positive and significant effect on the decision to purchase cosmetics in IPPNU Mojokerto Districts.

\section{ABSTRAK}

Penelitian ini bertujuan untuk mengetahui Pengaruh Brand Image dan Labelitas Halal terhadap Keputusan Pembelian kosmetik pada IPPNU di Kabupaten Mojokerto. Penelitian ini menggunakan jenis penelitian kuantitatif dengan menggunakan data primer dimana data ini diperoleh langsung dari pengisian kuesioner mengenai brand iamge dan labelitas halal terhadap keputusan pembelian produk kosmetik. Metode analisis data yang digunakan adalah metode analisis regresi berganda. Hasil penelitian menunjukkan bahwa secara simultan variabel brand image dan labelitas halal berpengaruh signifikan terhadap keputusan pembelian kosmetik IPPNU di Kabupaten Mojokerto. Variabel brand image secara parsial berpengaruh signifikan dan positif terhadap keputusan pembelian kosmetik pada IPPNU di Kabupaten Mojokerto. Variabel labelitas halal secara parsial berpengaruh signifikan dan positif terhadap keputusan pembelian kosmetik pada IPPNU di Kabupaten Mojokerto. 


\section{Pendahuluan}

Industri kosmetik saat ini berkembang pesat dengan presentase pada tahun 2019 yaitu mencapai 9\%. ${ }^{1}$ Perkembangan ini menimbulkan persaingan ketat sehingga mengharuskan perusahaan-perusahaan harus meningkatkan keunggulan produk agar memiliki daya saing. Selain itu, pertumbuhan pasar industri kosmetik didorong dengan pergeseran tren kecantikan dengan munculnya jenis produk kosmetik kecantikan untuk konsumen. Pertumbuhan juga didorong dengan permintaan pasar dalam negeri dan pengeluaran yang semakin meningkat di setiap tahun. Hal ini diikuti dengan gaya hidup masyarakat yang mulai memandang produk perawatan tubuh sebagai kebutuhan utama. ${ }^{2}$

Saat ini produk kosmetik sudah menjadi kebutuhan utama untuk para perempuan yang merupakan sasaran terpenting dari perindustrian kosmetik. ${ }^{3}$ Adapun pertumbuhan penduduk perempuan di Indonesia mencapai 132,89 juta jiwa, sehingga sangat mempengaruhi pertumbuhan industri kosmetik. ${ }^{4}$ Keinginan konsumen pada pembelian produk sangat mempengaruhi banyaknya produk kosmetik di pasaran sehingga berdampak pada naiknya pembelian.

Indonesia yaitu Negara bermayoritas agama Islam dimana jumlahnya 87,20 \%. Indonesia, Negara dengan penduduk muslim terbesar di dunia. ${ }^{5}$ Oleh karena itu di Indonesia keperluan terhadap kehalalan kosmetik begitu penting. Sedangkan di pasaran kosmetik juga masih banyak produk yang tidak memiliki label halal.

Terdapat perbedaan pada pola pembelian konsumen karena adanya perbedaan selera, usia, tingkat pendidikan, dan pendapatan, sehingga barang yang dibeli juga berbeda tergantung dari selera konsumen. Banyaknya produk yang tersedia di pasar terdapat beberapa peristiwa yang mempengaruhi pilihan konsumen untuk memperoleh suatu produk. Faktor tersebut yakni kebudayaan, sosial, pribadi dan psikologis. Menurut kotler \& amstrong, keputusan membeli seseorang yang awalnya

\footnotetext{
${ }^{1}$ Zainal Arif, "Optimalisasi Peluang Dan Tantangan Ekonomi Islam Dalam Menghadapi Masyarakat Ekonomi Asean," Al Maal: Journal of Islamic Economics and Banking 1, no. 1 (7 Juli 2019): 89-99, https://doi.org/10.31000/almaal.v1i1.1817.

2 “Kemenperin Sebut Industri Kosmetik Tumbuh Signifikan Di 2020," merdeka.com, 17 Februari 2021, https://www.merdeka.com/uang/kemenperin-sebut-industri-kosmetik-tumbuh-signifikan-di2020.html.

${ }^{3}$ Sri Arlina, "Perlindungan Konsumen Dalam Transaksi Jual Beli Online Produk Kosmetik (Pemutih Wajah) yang Mengandung Zat Berbahaya Berdasarkan Undang - Undang Nomor 8 Tahun 1999," UIR Law Review 2, no. 1 (2018): 317, https://doi.org/10.25299/uirlrev.2018.2.01.991.

4 "Jumlah Penduduk Indonesia 2019 Mencapai 267 Juta Jiwa," diakses 29 Juni 2021, https://databoks.katadata.co.id/datapublish/2019/01/04/jumlah-penduduk-indonesia-2019mencapai-267-juta-jiwa.

5 "Indonesia, Negara dengan Penduduk Muslim Terbesar Dunia" diakses 29 Juni 2021, https://databoks.katadata.co.id/datapublish/2019/09/25/indonesia-negara-dengan-pendudukmuslim-terbesar-dunia.
} 
dipengaruhi oleh lingkungan, kebudayaan, keluarga dan lainya, akan terbentuk sikap dari diri individu, kemudian melaksanakan pembelian. ${ }^{6}$

Banyaknya produk kosmetik yang beredar di pasaran memengaruhi minat seseorang untuk melakukan keputusan pembelian. Pembelian produk kosmetik sekarang sudah tidak lagi memenuhi keinginan tetapi sebuah kebutuhan sesorang. ${ }^{7}$ Beberapa hal yang dapat memengaruhi keputusan pembelian konsumen terhadap suatu produk yaitu lingkungan, sosial, dan budaya yang membentuk sikap dan mengambil keputusan pembelian. ${ }^{8}$

Menurut Philip Kotler, keputusan pembelian ialah perbuatan dari konsumen untuk membeli ataupun tidak kepada produk. ${ }^{9}$ Macam macam faktor yang mempengaruhi konsumen dalam melakukan pembelian produk ataupun jasa, biasanya konsumen selalu mempertimbangkan kualitas produk, harga dan produk yang sudah dikenal masyarakat. ${ }^{10}$ Suatu brand produk terdapat perhatian dan pertimbangan untuk konsumen dalam melaksanakan kegiatan keputusan pembelian, yang mana di setiap produk mempunyai kualitas yang berbeda. Citra (image) menurut Kotler merupakan kesan terhadap sesuatu yang diperoleh melalui pengalaman dan pengetahuan. Keller juga berpendapat bahwa merek merupakan gambaran mengenai sesuatu yang telah diperoleh dan terekam dalam memori atau benak konsumen.

Agar dapat lebih mudah menciptakan keputusan pembelian terhadap produk atau jasa oleh konsumen maka brand yang diciptakan harus berkualitas. Penciptaan brand yang berkualitas ini kemudian akan menciptakan kepercayaan konsumen karena merasa produk yang dibeli mampu memenuhi harapan konsumen, terjamin kualitasnya. ${ }^{11} \mathrm{Hal}$ ini kemudian mempengaruhi sikap konsumen yaitu mereka akan semakin yakin dengan pilihannya dan konsumen akan menyukai brand, bahkan menganggap brand tersebut sebagai bagian dari dirinya.

Ada berbagai hal yang harus dilihat konsumen sebelum menggunakan kosmetik, yaitu dengan memperhatikan adanya jaminan keamanan dan kenyamanan dalam mengkonsumsi suatu produk kosmetik. Jaminan tersebut dapat diperoleh konsumen

\footnotetext{
${ }^{6}$ Hery, Manajemen Pemasaran (Gramedia Widiasarana Indonesia, 2019).

${ }^{7}$ Stevia Septiani \& Retno Indraswari, "Faktor - Faktor yang Memengaruhi Perilaku Konsumen Produk Kosmetik Halal di Kota Bogor," Jurnal Manajemen dan Organisasi 9, no. 1 (2018): 60, https://doi.org/10.29244/jmo.v1i1.25370.

8 Hery.

9 Philip Kotler dan Kevin Lane Keller, Manajemen Pemasaran, (Erlangga, 2021), https://ecampus.unusia.ac.id/repo/handle/123456789/9531.

${ }^{10}$ Harun Al Rasyid \& Agus Tri Indah, "Pengaruh Inovasi Produk dan Harga Terhadap Keputusan Pembelian Sepeda Motor Yamaha di Kota Tangerang Selatan," Perspektif 16, no. 1 (2018).

${ }^{11}$ Ummi Lisawati \& Ritantri Kristina, “Pengaruh Brand Image @Gopayindonesia Terhadap Tingkat Kepercayaan Pelanggan," Pantarei 4, no. 1 (2020).
} 
dengan melihat bingkisan produk yang ada label dari BPOM dan label halal MUI disertai dengan adanya nomor registrasi dalam kemasan produk. ${ }^{12}$

Tabel 1. Daftar Kosmetik TopBrand 2019

\begin{tabular}{lll}
\hline No & Brand & BTI 2019 \\
\hline 1 & Wardah & $15,5 \%$ \\
\hline 2 & Pond's & $8,2 \%$ \\
\hline 3 & May belline & $7,8 \%$ \\
\hline 4 & Garnier & $5,4 \%$ \\
\hline 5 & Citra & $4,3 \%$ \\
\hline 6 & Viva & $3,9 \%$ \\
\hline 7 & Latulipe & $3,7 \%$ \\
\hline 8 & Revlon & $3,2 \%$ \\
\hline 9 & Oriflame & $2,1 \%$ \\
\hline 10 & Mustika ratu & $1,6 \%$ \\
\hline 11 & Biore & $1,6 \%$ \\
\hline 12 & Sariayu & $1,5 \%$ \\
\hline 13 & Ovale & $1,4 \%$ \\
\hline 14 & Pixy & $1,3 \%$ \\
\hline 15 & Vaselin & $1,2 \%$ \\
\hline 16 & Marcks & $1,2 \%$ \\
\hline 17 & Marina & $1,1 \%$ \\
\hline 18 & Olay & $0,9 \%$ \\
\hline 19 & L'oreal & $0,8 \%$ \\
\hline 20 & Nivea & $0,7 \%$ \\
\hline Sumber: Topbrand award.com/ Top Brand Index (2019) & \\
\hline & & M $\%$ \\
\hline 1
\end{tabular}

Tabel diatas menunjukkan bahwa kosmetik halal sangat diminati oleh masyarakat dengan wardah yang memiliki Top Brand kosmetik 2019 sebesar 15,5\%. Memang sudah menjadi kewajiban setiap muslim untuk memastikan bahwa produk kosmetik yang dipakai adalah halal, yang dapat dengan dilihat dengan cara mengecek label

\footnotetext{
12 “Peraturan Pemerintah Nomor 69 Tahun 1999," Pusat Data Hukumonline.com, diakses 29 Juni 2021 , https://m.hukumonline.com/pusatdata/detail/539/peraturan-pemerintah-nomor-69-tahun1999/document.
} 
halal pada kemasan kosmetik tersebut. ${ }^{13} \mathrm{Hal}$ ini juga merupakan hal yang penting untuk diperhatikan.

Penggunaan kosmetik ditujukan untuk memperindah atau memoles penampilan fisik agar tampak lebih menarik. Perempuan IPPNU yang menjadi pengguna kosmetik agar berpenampilan lebih cantik dan menarik merupakan salah satu konsumen kosmetik. Sebagai seorang perempuan kecantikan dan penampilan menarik menjadi kebutuhan. Tetapi apakah IPPNU Kabupaten Mojokerto menggunakan produk kosmetik yang mempunyai label halal. Apakah brand image dan label halal dapat menjadi tolak ukur perempuan dalam menggunakan sedangkan perempuan IPPNU adalah konsumen muslim.

Ikatan Pelajar Putri Nahdlatul Ulama (IPPNU) yaitu organisasi yang terfokus di pendidikan dan perkembangan sumber daya pelajar, mahasiswa, dan santri. IPPNU lahir sejak 2 Maret 1955 di Malang di bawah naungan organisasi masyarakat terbesar di Indonesia yaitu NU. IPPNU beranggotakan 3 juta anggota berada di 2000 sekolah SLTP/SLTA, 320 kabupaten/kota di 33 provinsi, sedangkan di Mojokerto sendiri anggota IPPNU ada sekitar 2300 anggota.

Berdasarkan latar belakang tersebut, penulis tertarik untuk melakukan riset tersendiri tentang pengaruh brand image dan label halal terhadap keputusan pembelian kosmetik dengan komunitas IPPNU Kabupaten Mojokerto sebagai respondennya.

\section{Landasan Teori}

\section{Keputusan Pembelian}

Perilaku konsumen merupakam proses atau aktivitas mulia proses mencari, memilih, membeli, menggunakan, serta mengevaluasi produk maupun jasa dengan tujuan untuk emenuhi kebutuhan dan keinginan. Perilaku konsumen biasanya digunakam dalam hal yang berkaitan dengan dasar perilaku konsumen untuk membuat keputusan dalam proses pembelian. ${ }^{14}$

Menurut Philip Kotler, keputusan pembelian merupakan tindakan konsumen untuk memilih membeli atau tidak membeli produk tersebut. Berikut merupakan beberapa hal yang dapat mempengaruhi konsumen dalam melakukan pembelian produk atau jasa, para konsumen akan mempertimbangkan kualitas, harga dan produk yang sudah dikenal oleh masyarakat ${ }^{15}$. Indikator yang berkaitan dengan keputusan pembelian menurut Philip Kotler sebagai berikut : Kualitas, Harga, Produk yang sudah dikenal.

\footnotetext{
${ }^{13}$ Rahmi Ayunda \& Viola Zahra Ananda Kusuma, "Perlindungan Hukum Bagi Konsumen Muslim Terhadap Produk Kosmetik yang Memiliki Kandungan Non-Halal di Indonesia," Maleo Law Journal 5, no. 1 (2021): 132.

${ }^{14}$ M. Anang Firmansyah, Perilaku Konsumen (Sikap dan Pemasaran) (Penerbit Qiara Media, 2019).

${ }^{15}$ Keller, Manajemen Pemasaran, 220.
} 


\section{Brand Image}

Image (citra) adalah persepsi masyarakat terhadap perusahaan atau produk. Brand (merk) menjadi hal yang terpenting terhadap suatu produk.Merk atau brand ini dapat menjadi suatu nilai tambah terhadap barang atau jasa. Nilai tambah inilah yang sangat menguntungkan bagi para prdusen dan perusahaan sehingga sangat perlu bagi mereka untuk memperoleh citra yang baik dari masyarakat. Para produsen maupun perusahaan harus memiliki keunggulan atau ciri khas dalam merk atau brand suatu produk agar para konsumen menjadi target marketnya.

Citra (image) merupakan kesan terhadap sesuatu yang diperoleh melalui pengalaman dan pengetahuan. Keller juga berpendapat bahwa merk merupakan gambaran mengenai sesuatu yang telah diperoleh dan terekam dalam memori atau benak konsumen

Merk (brand) adalah simbol, nama, istilah, rancangan, kombinasi keseluruhan yang bertujuan untuk mengidentifikasi barang atau jasa produsen atau kelompok penjual untuk mendiferensiasikan dari barang atau jasa dari berbagai pesaing. Merk berperan sebagai bentuk tanggung jawab produsen kepada konsumen untuk memberikan jaminan perlindungan. Selain perlindungan terhadap konsumen, merek juga melindungi perusahaan dengan adanya hak paten, pengemasan yang memiliki merek dagang terdaftar dan pada industri manufaktur dilindungi oleh hak cipta (Phillip Kotler \& Keller). ${ }^{16}$

Terdapat tiga indikator untuk mengukur citra merek suatu produk menurut Keller, diantaranya sebagai berikut:

a. Kekuatan (Strenghness) merupakam Kekuatan yang dimiliki oleh suatu merek berupa keunggulan secara fisik yang tidak dapat ditemukan pada merek lain. Keunggulan fisik tersebut dapat berupa manfaat produk, harga serta penampilan pendukung lainnya.

b. Keunikan (Uniqueness) merupakan Ciri khusus yang memiliki fungsi sebagai pembeda dari merek lainnya. Keunikan berasal dari atribut produk yaitu, diferensiasi yang memberikan penjelasan mengapa suatu produk yang sama dapat dikatakan memiliki perbedaan sehingga para konsumen dianjurkan untuk menggunakan produk tersebut. Keunikan utama dari suatu produk adalah perbedaan yang mendominasi produk yang dimiliki dengan produk perusahaan lain seperti harga, kemasan, informasi serta keamanan.

c. Kesukaan (Favorable) Berhubungan dengan kemampuan menciptakan merek yang mudah diingat oleh para konsumen. Merek dapa dikategorikan favorable apabila merek tersebut mudah untuk diucapkan, mudah diingat, mudah digunakan, konsumen, merasa cocok dalam menggunakan produk tesebut, serta adanya kesesuaian antara kesan yang diperoleh dengan citra yang diinginkan oleh konsumen.

\footnotetext{
${ }^{16}$ Keller, 332.
} 


\section{Labelisasi halal}

Labelisasi merupakan kata dari bahasa Inggris yaitu "Label" yang berarti "nama" atau "memberi nama". Sedangkan secara terminologi, label merupakan bagian dari keterangan suatu barang yang menjelaskan tentang barang tersebut atau penjualnya. Pada beberapa produk label dapat berisi komposisi, indikasi, cara pemakaian, penyimpanan, batch nomor, tanggal kadaluarsa, berat netto, produsen, maupun tempat produksi.

Label pada sebuah produk ini sangat bermanfaat dan memiliki banyak fungsi. Berikut merupakan beberapa fungsi label Menurut Kotler: ${ }^{17}$

a. Mengidentifikasi (identify) yaitu label yang dapat menerangkan mengenai produk yang akan dipasarkan.

b. Nilai atau kelas (grade) yaitu label menunjukkan nilai, kualitas maupun mutu sebuah produk. Misal produk buah peach kalengan diberi nilai $A, B$, dan $\mathrm{C}$ yang menunjukkan tingkatan kualitas sebuah produk.

c. Memberikan keterangan (describe) yaitu label menunjukkan keterangan produk dan hal-hal tentang produk. Sepertihalnya produsen,waktu pembuatan, komposisi bahan yang digunakan, dan cara penggunaan sebah produk itu sendiri.

d. Mempromosikan (promote) yaitu label dapat digunakan untuk mempromosikan atau menarik hati calon pembeli dengan diberi desain yang menarik.

Secara bahasa, kata halal berasal dari bahasa arab (halalan) yang berarti "melepaskan" dan "tidak terikat". Secara etimologi halal merupakan suatu kebebasan dari beberapa hal atau aturan-aturan yang melarangnya. Halal adalah sesuatu yang diperbolehkan menurut ajaran Islam, seperti yang telah terkandung dalam Firman Allah QS. Al-Maidah/5: 88

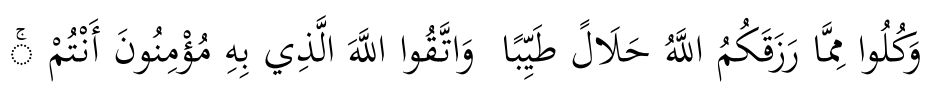

Artinya: Dan makanlah makanan yang halal lagi baik dari apa yang Allah telah rezekinya kepadamu, dan bertakwalah kepada Allah yang kamu beriman kepadanya.

Pasal 1 (3) dari PP No. 69 Tahun 1999 menentukan bahwa yang dimaksud dengan label pangan dan obat, serta kosmetik adalah: setiap keterangan mengenai produk yang berbentuk gambar, tulisan, kombinasi keduanya atau bentuk lain yang disertakan pada produk, dimasukkan ke dalam, ditempelkan pada atau merupakan bagian kemasan produk. $^{18}$

\footnotetext{
${ }^{17}$ Keller, 29.

18 “Peraturan Pemerintah Nomor 69 Tahun 1999."
} 
Pemberian label halal pada suatu produk ini mmiliki tujuan untuk memenuhi tuntutan pasar (konsumen) secara menyeluruh sehingga dapat digunakan oleh pembeli dengan sasaran luas. Apabila tuntutan tersebut bisa terpenuhi, maka perekonomian Indonesia dapat naik pesat dan mampu menjadi tuan rumah dari segala produk yang dipasarkan. Hal ini juga terakait mayoritas masyarakat Indonesia beragama Islam sehinga memiliki keharusan ntuk mengonsumsi produk-produk halal. Kehalalan produ bagi umat Islam merupakan suatu yang sangat mendasar untuk melindungi akidah konsumen, sehingga dapat merasa aman tanpa kekhawatiran untuk menggunakan produk-produknya. Indikator label halal menurut Pasal 1 (3) dari PP No. 69 Tahun 1999 sebagai berikut:

a. Gambar, merupakan hasil visualisasi maupun tiruan yang mendespripsikan produk dalam bentuk ataupun pola (hewan, oran, tumbuhan, ataupun logo)

b. Tulisan, merupakan keterangan berupa kata-kata yang menjelaskan secara singkat suatu produk.

c. Kombinasi gambar dan tulisan, merupakan gabungan antara hasil gambar dan hasil tulisan yang dijadikan menjadi satu bagian.

d. Menempel pada kemasan, dapat diartikan sebagai sesuatu yang melekat pada kemasan (pelindung suatu produk).

\section{Metode Penelitian}

Penelitian ini merupakan jenis penelitian kuantitatif, yang mana untuk membuktikan hipotesis yang telah dibuat penulis. Penelitian ini menggunakan 3 variabel yaitu Brand Image dan Labelisasi Halal sebagai variabel bebas. Sedangkan Keputusan Pembelian sebagai variabel terikat.

Penelitian ini menggunakan pendekatan asosiatif yaitu penelitian ini menjabarkan hubungan antara sebab akibat dalam bentuk pengaruh antar variabel melalui pengujian hipotesis. Penelitian asosiatif memiliki hubungan antara dua variable atau lebih. Asosiatif yang dimaksud dalam penelitian ini yaitu ada tidaknya pengaruh labelitas halal dan brand image terhadap keputusan pembelian muslimah IPPNU di Kabupaten Mojokerto.

Populasi penelitian ini adalah seluruh anggota muslimah IPPNU Kab. Mojokerto yang berjumlah 2.300 anggota. Sampel dihitung dengan tingkat eror sebesar 10\%. Agar peneliti mendapatkan sampel yang dapat menggambarkan populasi, maka dalam penelitian ini diambil jumlah sampel sebanyak 96 anggota dari total anggota sebanyak 2.300 yang diambil dengan menggunakan Rumus Slovin.

Keterangan :

$\mathrm{N}=$ Jumlah populasi

$d=$ standar error $10 \%$ atau 0,1 


$$
\begin{aligned}
\mathrm{n} & =\frac{\mathrm{N}}{\mathrm{N} \cdot \mathrm{d}^{2}+1} \\
& =\frac{2300}{2300.0,1^{2}+1}=\frac{2300}{24}=96
\end{aligned}
$$

Sesuai perhitungan di atas, dari populasi yang berjumlah 2.300 anggota maka jumlah sampel yang di dapatkan adalah 96 orang.

Data yang didapat dalam penelitian ini dari hasil angket yang telah dibagi di anggota IPPNU Kabupaten Mojokerto. Pembagian angket melalui google form dikarenakan keadaan covid yang tidak memungkinkan untuk berkerumun dengan orang banyak.

Metode analisi data yang digunakan adalah regresi linier berganda. Digunakan untuk menguji pengaruh antara variabel independen (Brand Image dan Labelisasi Halal) dengan variabel dependen (Keputusan Pembelian). Perhitungan dilakukan dengan program SPSS.

Model hubungan variabel dianalisis sesuai dengan persamaan regresi :

$Y=a+b 1 X 1+b 2 \times 2+$ $+b n X n$

Dimana :

$\mathrm{Y} \quad=$ Keputusan pembelian

a $\quad=$ Konstanta

b1 = Koefisien regresi parsial variabel brand image

b2 = Koefisien regresi parsial labelitas halal

X1 = Variabel brand image

X2 = Variabel labelitas halal

Hipotesis ini diujikan kepada peneliti untuk mengetahui ada atau tidaknya pengaruh yang signifikan dari variabel independen (Brand Image dan Labelitas Halal) terhadap variabel depenten (Keputusan Pembelian) baik secara persial atau simultan.

\section{Hasil Analisis Data}

\section{Uji Normalitas}

Uji Normalitas dilakukan untuk melihat data yang dipakai apakah berdistribusi normal atau tidak. Jika data yang dipakai berdistribusi normal maka dikatakan regresi baik. Jika data berdistribusi normal data tersebut dianggap bisa mewakili populasi. 
Tabel 2. Hasil Uji Normalitas

\begin{tabular}{|c|c|c|}
\hline & & Unstandardized Residual \\
\hline \multicolumn{2}{|l|}{$\mathrm{N}$} & 96 \\
\hline \multirow[t]{2}{*}{ Normal Parameters ${ }^{\mathrm{a}, \mathrm{b}}$} & Mean & .0000000 \\
\hline & Std. Deviation & 1.35264796 \\
\hline \multirow[t]{3}{*}{ Most Extreme Differences } & Absolute & .048 \\
\hline & Positive & .048 \\
\hline & Negative & -.038 \\
\hline \multicolumn{2}{|l|}{ Test Statistic } & .048 \\
\hline \multicolumn{2}{|l|}{ Asymp. Sig. (2-tailed) } & $.200^{c, d}$ \\
\hline
\end{tabular}

Sumber: Diolah penulis, 2021.

Berdasarkan hasil uji yang dilakukan menggunakan metode Kolmogorof-Smirnof Test ini diketahui signifikan pada uji diatas sebesar 0,200. Hal ini menunjukkan bahwa hasilnya lebih besar dari taraf signifikan sebesar 0,05 . Jadi menunjukkan uji normalitas pada penelitian ini berdistribusi normal

\section{Analisis Regresi Linier Berganda}

Berikut hasil perhitungan regresi linier berganda dari Brand Image dan Labelisasi Halal terhadap keputusan pembelian dengan program SPSS:

Tabel 3. Hasil Uji Regresi Linier Berganda

\begin{tabular}{|c|c|c|c|c|c|c|}
\hline \multirow[b]{2}{*}{ Model } & & \multicolumn{2}{|c|}{$\begin{array}{l}\text { Unstandardized } \\
\text { Coefficients }\end{array}$} & \multicolumn{2}{|c|}{$\begin{array}{l}\text { Standardized } \\
\text { Coefficients }\end{array}$} & \multirow[b]{2}{*}{ Sig. } \\
\hline & & B & Std. Error & Beta & $\mathbf{T}$ & \\
\hline \multirow[t]{3}{*}{1} & (Constant) & 3.970 & 1.877 & & 2.115 & .037 \\
\hline & brand_image & .646 & .073 & .659 & 8.852 & .000 \\
\hline & labelitas_halal & .148 & .054 & .205 & 2.749 & .007 \\
\hline
\end{tabular}

Sumber: Diolah penulis, 2021.

Berdasarkan tabel diatas maka diperoleh persamaan sebagai berikut :

$Y=3,970+0,646 \times 1+0,148 \times 2$

a. Diketahui nilai kostanta 3,970 yang mana jika Brand Image dan Labelisasi Halal nilainya 0, maka nilai keputusan pembelian sebesar 3,970.

b. Nilai koefisien X1 0,646 artinya jika Brand Image mengalami kenaikan, maka keputusan pembelian akan meningkat sebesar 1,646 dengan asumsi variabel independen lainya bernilai tetap. 
c. Nilai koefisien regresi X2 0,148 artinya jika Labelisasi Halal mengalami kenaikan maka keputusan pembelian akan meningkat sebesar 1,646 dengan asumsi variabel independen lainya tetap.

3. Uji Parsial (T)

Tabel 4. Hasil uji T

\begin{tabular}{cccc}
\hline No & Variabel & $\mathbf{T}$ & Sig \\
\hline $\mathbf{1}$ & Brand Image (X1) & 8.852 & 0 \\
\hline $\mathbf{2}$ & Labelitas Halal (X2) & 2.749 & 0.007 \\
\hline
\end{tabular}

Sumber: Diolah penulis, 2021.

Berdasarkan tabel diatas dijelaskan bahwa nilai signifikansinya yaitu :

a. Brand Image (X1) adalah diketahui nilai signifikansi (sig) 0,000 0,05 maka $\mathrm{HO}$ ditolak dan $\mathrm{H} 1$ diterima yaitu terdapat pengaruh positif yang signifikan secara persial dari variabel brand image (X1) terhadap keputusan pembelian pada IPPNU di Kab Mojokerto. Nilai $\mathrm{t}$ hitung 8,852 dengan $t$ tabel 1,986 .

b. Labelisasi Halal (X2) adalah diketahui nilai signifikansi (sig) 0,007 $<0,05$ maka $\mathrm{HO}$ ditolak dan $\mathrm{H} 1$ diterima yaitu terdapat pengaruh positif yang signifikan secara parsial dari variabel labelitas halal (X2) terhadap keputusan pembelian pada IPPNU pada Kabupaten Mojokerto. Nilai $t$ hitung 2,749 dengan $t$ tabel 1,986.

4. Uji Simultan (F)

Hasil uji F dapat dilihat pada tabel dibawah ini :

Tabel 5. Hasil Uji F

ANOVA $^{\mathrm{a}}$

\begin{tabular}{ccccccc}
\hline \multirow{2}{*}{ Model } & $\begin{array}{c}\text { Sum of } \\
\text { Squares }\end{array}$ & Df & $\begin{array}{c}\text { Mean } \\
\text { Square }\end{array}$ & $F$ & Sig. \\
\hline \multirow{2}{*}{1} & Regression & 270.141 & 2 & 135.070 & 72.269 & $.000^{\mathrm{b}}$ \\
\cline { 2 - 7 } & Residual & 173.817 & 93 & 1.869 & & \\
\cline { 2 - 7 } & Total & 443.958 & 95 & & & \\
\hline
\end{tabular}

Sumber: Diolah penulis, 2021.

Dari uji ANOVA atau $F$ diatas dapat diperoleh bahwa $F$ hitung menunjukkan nilai sebesar 72,269 dengan hasil signifikan sebesar 0,000, sedangkan degree of freedom 2 (n-k-1, 96-2-1=93) pada angka 2 dan 93 dalam tabel $\mathrm{F}$ sebesar 3,09, yang menunjukkan bahwa nilai $\mathrm{F}$ hitung 72,269 lebih besar dari nilai $F$ tabel =3,09. Dan nilai signifikan sebesar 0,000<0,05.

Jadi dapat dilihat bahwa variabel Brand Image (X1), Labelisasi Halal (X2) secara simultan berpengaruh terhadap Keputusan Pembelian (Y). Secara 
hipotesis maka $\mathrm{H} 1$ diterima dan $\mathrm{HO}$ ditolak yaitu terdapat pengaruh variabel Brand Image dan Labelisasi Halal secara simultan terhadap keputusan pembelian kosmetik pada IPPNU di Kabupaten Mojokerto.

\section{Koefisien Determinasi}

Tabel 6. Hasil Koefisien Determinasi

Model Summary

\begin{tabular}{ccccc}
\hline Model & $R$ & R Square & $\begin{array}{c}\text { Adjusted R } \\
\text { Square }\end{array}$ & $\begin{array}{c}\text { Std. Error of } \\
\text { the Estimate }\end{array}$ \\
\hline 1 & $.780^{\mathrm{a}}$ & .608 & .600 & 1.367 \\
\hline \multicolumn{2}{l}{ Sumber: Diolah penulis, 2021.}
\end{tabular}

Berdasarkan analisis tabel diatas R2 diperoleh hasil sebesar 0,608 atau 60.8\% yang artinya bahwa pengaruh brand image dan labelisasi halal terhadap keputusan pembelian yaitu sebesar $60,8 \%$ dan memiliki sisa $39,2 \%$ yang dipengaruhi oleh variabel lain di penelitian lain.

\section{Pembahasan}

Berdasarkan hasil uji F di atas, dapat disimpulkan bahwa brand image dan labelitas halal secara simultan memiliki pengaruh signifikan terhadap keputusan pembelian kosmetik pada IPPNU di Kabupaten Mojokerto. Sebab nilai $F$ hitung senilai 72,269 lebih besar jika dibandingkan dengan nilai $F$ tabel 3,09 dengan signifikan 0,000. Artinya semakin tinggi brand image dan labelitas halal secara bersamaan maka semakin tinggi juga keputusan pembelian kosmetik pada IPPNU diKabupaten Mojokerto. Keputusan pembelian dipengaruhi sebesar $60,8 \%$ oleh variabel brand image dan labelitas halal, dan sisanya 39,2\% dipengaruhi oleh variabel lain yang ada di luar penelitian ini.

Secara persial pengaruh brand image terhadap keputusan pembelian kosmetik pada IPPNU di Kabupaten Mojokerto dapat dilihat pada uji yang dilakulan penelitian ini yaitu uji koefisien regresi secara persial uji ini berfungsi untuk mengetahui apakah dalam model regresi ini yaitu variabel bebas (X1) secara persial berpengaruh signifikan terhadap variabel terikat $(\mathrm{Y})$.

Diketahui hasil analisis regresi diperoleh $\mathrm{t}$ hitung untuk variabel brand image sebesar 8,852 yang dibandingkan dengan thitung dan ttabel. Di peroleh tabel 1,986. Dimana Nilai dari thitung lebih besar dari nilai ttabel yaitu 8,852 $>1,986$ dan signifikansi (sig) 0,000 $<0,05$ yang mempunyai arti $\mathrm{H} 1$ diterima dan $\mathrm{HO}$ ditolak. Ini berarti bahwa terdapat pengaruh yang signifikan antara brand image terhadap keputusan pembelian kosmetik pada IPPNU di Kabupaten Mojokerto, yang berarti secara persial terhadap pengaruh yang nyata antara brand image terhadap keputusan pembelian. Maka dapat disimpulkan bahwa faktor brand image mempengaruhi secara signifikan terhadap keputusan pembelian kosmetik pada IPPNU di Kabupaten 
Mojokerto. Angka koefisien regresi yang besar adalah 0,646 yang berarti jika variabel independen lain nilainya tetap dan variabel brand iamge mengalami kenaikan, maka keputusan pembelian akan meningkat sebesar $64,6 \%$. Penelitian yang dilakukan Yusnita Siregar ${ }^{19}$ memperoleh hasil penelitian yang sama bahwa brand image berpengaruh terhadap keputusan pembelian.

Hasil penelitian diketahui bahwa variabel labelisasi halal berpengaruh secara positif dan signifikan terhadap keputusan pembelian hal ini dapat dilihat dari signifikansi labelisasi halal sebesar 0,007 yang berarti lebih kecil dari tingkat signifikansi yang digunakan yaitu 0,05. Dan dapat dilihat dari $t$ hitung sebesar 2,749 yang berarti $t$ hitung $>t$ tabel yaitu 1,984. Koefisien regresi label halal sebesar 0,148 yang menyatakan bahwa setiap terjadi kenaikan nilai labelisasi halal sebesar satu, maka akan diikuti dengan kenaikan keputusan pembelian sebesar 0,148. Maka dengan ini Ha diterima, secara parsial labelisasi halal berpengaruh positif dan signifikan terhadap keputusan pembelian produk kosmetik. Hal ini menunjukkan bahwa labelisasi halal berpengaruh positif terhadap keputusan pembelian.

Diketahui hasil analisis regresi didapat thitung bagi variabel labelisasi halal 2,749 yang dibandingkan dengan thitung dan ttabel. Di peroleh ttabel 1,986. Dimana thitung lebih besar dari nilai ttabel yaitu 2,749 >1,986 dan signifikansi (sig) 0,007 < 0,05 yang mempunyai arti $\mathrm{H} 1$ diterima dan $\mathrm{HO}$ ditolak. Artinya ada pengaruh yang signifikan diantara labelisasi halal terhadap keputusan pembelian kosmetik IPPNU di Kabupaten Mojokerto, yang berarti secara persial terhadap pengaruh yang nyata antara brang image terhadap keputusan pembelian. Hasil ini senada dengan penelitian yang dilakukan Siti Suriati Rahmi ${ }^{20}$ memperoleh hasil penelitian yang sama bahwa label halal berpengaruh positif dan signifikan terhadap keputusan pembelian.

\section{Penutup}

Brand image terhadap keputusan pembelian kosmetik pada IPPNU di Kabupaten Mojokerto secara persial berpengaruh signifikan. Brand image berpengaruh pada pengambilan keputusan pembelian kosmetik, dengan ini hal tersebut dapat digunakan oleh perusahaan produk kosmetik untuk tetap menjaga bahkan meningkatkan brand image produk kosmetik.

\footnotetext{
${ }^{19}$ Yusnita Siregar, "Pengaruh brand image dan label halal terhadap keputusan pembelian kosmetik Wardah pada mahasiswi jurusan ekonomi syariah fakultas ekonomi dan bisnis Islam IAIN Padangsidimpuan" (undergraduate, IAIN Padangsidimpuan, 2017), http://etd.iainpadangsidimpuan.ac.id/3694/.

${ }^{20}$ Rahmawati Rahman, "Pengaruh Labelisasi Halal dan Citra Merek terhadap Keputusan Pembelian Produk Ponds White Beauty di Kecamatan Tamalate Kota Makassar (Ditinjau dari Perspektif Ekonomi Islam)" (diploma, Universitas Islam Negeri Alauddin Makassar, 2018), http://repositori.uinalauddin.ac.id/11796/.
} 
Labelisasi halal terhadap keputusan pembelian kosmetik pada IPPNU di Kabupaten Mojokerto secara persial berpengaruh signifikan. Labelisasi halal juga berpengaruh dalam pengambilan keputusan pembelian kosmetik. Hal ini dapat menambah daftar perijinan yang harus ditaati suatu perusahaan kosmetik. Perusahaan dengan konsep label halal lebih banyak disukai oleh konsumen, khususnya konsumen yang mulai beralih melakukan pembelian produk kosmetik yang sudah mencantumkan sertifikasi halal.

Brand image dan labelisasi halal secara simultan memiliki pengaruh signifikan terhadap keputusan pembelian kosmetik pada IPPNU di Kabupaten Mojokerto. Diharapkan untuk para wanita muslimah untuk lebih memperhatikan labelisasi halal dalam keputusan pembelian suatu produk kosmetik karena mengonsumsi suatu barang halal itu sudah kewajiban suatu muslim. Mengkonsumsi produk halal dianjukan untuk kebaikan manusia sendiri.

Peneliti selanjutnya diharapkan dapat menambah variabel lain seperti tingkat harda dan kualitas produk yang mana tidak ada dalam penelitian ini yang bisa memberikan kontribusi terhadap keputusan pembelian kosmetik

\section{Daftar Pustaka}

Al Rasyid, Harun \& Agus Tri Indah. "Pengaruh Inovasi Produk dan Harga Terhadap Keputusan Pembelian Sepeda Motor Yamaha di Kota Tangerang Selatan." Perspektif 16, no. 1 (2018).

Arif, Zainal. "Optimalisasi Peluang Dan Tantangan Ekonomi Islam Dalam Menghadapi Masyarakat Ekonomi Asean." Al Maal: Journal of Islamic Economics and Banking 1, no. 1 (7 Juli 2019): 89-99. https://doi.org/10.31000/almaal.v1i1.1817.

Arlina, Sri. "Perlindungan Konsumen Dalam Transaksi Jual Beli Online Produk Kosmetik (Pemutih Wajah) yang Mengandung Zat Berbahaya Berdasarkan Undang - Undang Nomor 8 Tahun 1999." UIR Law Review 2, no. 1 (2018): 317, https://doi.org/10.25299/uirlrev.2018.2.01.991

Ayunda, Rahmi \& Viola Zahra Ananda Kusuma. "Perlindungan Hukum Bagi Konsumen Muslim Terhadap Produk Kosmetik yang Memiliki Kandungan Non-Halal di Indonesia." Maleo Law Journal 5, no. 1 (2021): 132.

Hery. Manajemen Pemasaran. Gramedia widiasarana indonesia, 2019.

kumparan. "Daftar Kosmetik Halal di Indonesia yang Telah Disertifikasi MUI." Diakses 29 Juni 2021. https://kumparan.com/kumparanstyle/daftar-kosmetik-halaldi-indonesia-yang-telah-disertifikasi-mui-1548333618812262658.

"Indonesia, Negara dengan Penduduk Muslim Terbesar Dunia" Diakses 29 Juni 2021. https://databoks.katadata.co.id/datapublish/2019/09/25/indonesia-negaradengan-penduduk-muslim-terbesar-dunia. 
"Jumlah Penduduk Indonesia 2019 Mencapai 267 Juta Jiwa" Diakses 29 Juni 2021. https://databoks.katadata.co.id/datapublish/2019/01/04/jumlah-pendudukindonesia-2019-mencapai-267-juta-jiwa.

Keller, Philip Kotler dan Kevin Lane. Manajemen Pemasaran. Erlangga, 2021. https://ecampus.unusia.ac.id/repo/handle/123456789/9531.

Lisawati, Ummi \& Ritantri Kristina. "Pengaruh Brand Image @Gopayindonesia Terhadap Tingkat Kepercayaan Pelanggan." Pantarei 4, no. 1 (2020).

merdeka.com. "Kemenperin Sebut Industri Kosmetik Tumbuh Signifikan di 2020," 17 Februari 2021. https://www.merdeka.com/uang/kemenperin-sebut-industrikosmetik-tumbuh-signifikan-di-2020.html.

M. Anang Firmansyah, Perilaku Konsumen (Sikap dan Pemasaran). Penerbit Qiara Media, 2019.

Pusat Data Hukumonline.com. "Peraturan Pemerintah Nomor 69 Tahun 1999." $\begin{array}{llll}\text { Diakses } & 29 & 2021 .\end{array}$ https://m.hukumonline.com/pusatdata/detail/539/peraturan-pemerintahnomor-69-tahun-1999/document.

Rahman, Rahmawati. "Pengaruh Labelisasi Halal dan Citra Merek terhadap Keputusan Pembelian Produk Ponds White Beauty di Kecamatan Tamalate Kota Makassar (Ditinjau dari Perspektif Ekonomi Islam)." Diploma, Universitas Islam Negeri Alauddin Makassar, 2018. http://repositori.uinalauddin.ac.id/11796/.

Septiani, Stevia \& Retno Indraswari. "Faktor - Faktor yang Memengaruhi Perilaku Konsumen Produk Kosmetik Halal di Kota Bogor." Jurnal Manajemen dan Organisasi 9, no. 1 (2018). https://doi.org/10.29244/jmo.v1i1.25370.

Siregar, Yusnita. "Pengaruh Brand Image dan Label Halal Terhadap Keputusan Pembelian Kosmetik Wardah pada Mahasiswi Jurusan Ekonomi Syariah Fakultas Ekonomi dan BISNIS ISLAM IAIN Padangsidimpuan." Undergraduate, IAIN Padangsidimpuan, 2017. http://etd.iain-padangsidimpuan.ac.id/3694/.

Sumarwan, Ujang. Riset Pemasaran dan Konsumen Seri: 3. PT Penerbit IPB Press, 2019. 